\title{
The Jewish community in the post-apartheid era: same narrative, different meaning
}

\author{
Chaya Herman
}

\begin{abstract}
The article explores the transformation of the Jewish community in South Africa and the strategies that have been pursued by the community to forge a new identity whereby secular Zionism has been shifted towards religious Zionism; moderate Orthodoxy has been replaced with Ultra Orthodoxy and the perceived unity of the community has been maintained by advancing exclusion and seclusion. The article investigates how this identity has evolved in response to local and global changes. It argues that South Africa's transformation to democracy has not seemed to open up the community to new possibilities, but has instead made it more inward-looking and insular. The article calls to the community to face and debate its shifting identity, to broaden its boundaries and to create a new content that celebrates diversity, inclusivity, tolerance and openness to others.
\end{abstract}

Ethnic groups are defined by both content (what they share) and boundaries (who is in and who is not in the group) (Gitelman 1998). In the Jewish case, religion has been the dominant marker of Jewishness for many centuries. However, the hegemonic position of the religious discourse has been threatened in the modern period by the emergence of both secularism and Zionism. Zionism was conceived as a secular political nationalist movement which offered a different concept of Jewishness and tried to transform the ethnic group into nation.

Many pessimistic scholars predict that the future of the Jewish Diaspora today is doubtful (Sheffer 2002). They argue that globalisation, pluralism, multiculturalism and increased tolerance toward the 'other' in democratic host countries, have sped up integration with and assimilation into the host community. Gitelman (1998) explains that Jews in the Diaspora remain an ethnic group but one that is eroding because its content is diminishing and its boundaries are blurring. He argues that 'thin culture' and 'symbolic ethnicity' are replacing 'thick culture' for most Jews. Furthermore, owing to ideological pluralism among Jews, any attempt to form consensus around the community's ethnic identity sparks tensions, debates and problems, some of which are difficult to resolve. The question is how does a community in Diaspora preserve its ethnic identity? How does a community reach a consensus on who has the right to speak for its members? What strategies have been pursued by ethnic community to define both its content and its 
boundaries? This article attempts to deal with these questions in the context of the Jewish community in South Africa at the beginning of the twenty first century.

The ethnic identity of Diaspora community is influenced by the culture of the host society and the culture within the ethnic community (Cohen 2004). In the case of the Jewish community in South Africa, the strategies that have been used by the community to ascertain its content and demarcate its boundaries relate directly to its history, relation to Israel and relation to the host community. The following sections provide a brief history of the Jewish community in South Africa and explore how its identity has evolved and shifted in response to political, social, ideological and economic transformations.

\section{The Jewish community in South Africa}

The South African Jewish community was first formed when a large number of British settlers arrived in the country in the early nineteenth century (Shimoni 2003). This was followed by a large influx of East European immigrants, the majority from Lithuania ${ }^{1}$, who arrived between 1880 and $1940^{2}$. Some immigrants arrived in the 1970s, mostly from Israel and from Southern African countries including Zimbabwe, Zambia and Namibia. At its peak in the 1970s, the Jewish population in South Africa was estimated at 118,000 and was spread throughout the country. Emigration from South Africa began in the mid 1970s as a result of political uncertainties, and continues to this day. The most popular destination for immigration is Australia, followed by the United States, Israel, the United Kingdom and Canada. The current Jewish population in South Africa (2005) is estimated at 80,000, concentrated mainly in Johannesburg and Cape Town.

A 1998 attitudinal survey ${ }^{3}$ showed a very well educated community by South African standards. Most employed persons held professional and managerial positions. Only about two per cent of the sample was employed in manual and unskilled jobs. The community prides itself on its low intermarriage rate ${ }^{4}$ and its well-organised community organisations (Aschheim 1970, Kopelowitz 1997/8).

The identity of the Jewish community in South Africa has been shaped by the political, social and economic processes in South Africa and Israel, wherein critical events occurred simultaneously. In 1948, at the same time that the State of Israel was established, the National Party won the general elections and thereafter instituted the apartheid regime in South Africa. In 1994, South Africa held its first democratic elections and Nelson Mandela was elected president of South Africa. In 1993, Israel signed the Oslo Accord, which gave Palestinians limited self-rule in Gaza and parts of the West Bank. The strong reactions to the Oslo Accord eventually led to the 
assassination of the Israeli Prime Minister, Yitzchak Rabin, on November 4, 1995. His assassin was an Israeli - a right-wing religious student. This gave a clear indication of the deep schism in Israeli society.

It appears, therefore, that in the 1990s, while South Africa was rapidly moving towards democracy and the construction of a national identity, Israel was in the midst of both an identity and a national crisis. This crisis related to the decline in the hegemony of the Zionist ideology which shaped the Jewish discourse from the end of the nineteenth century, and the emergence of Jewish fundamentalist-type groups - either those based on religious Zionism or those based on the Ultra Orthodoxy's rejection of Zionism. While Zionism maintained that anti-Semitism was the product of the 'abnormality' of Jewish life among gentiles and that the existence of a Jewish state, to which all Jews would immigrate, would eliminate hatred towards the Jews and thereby solve the 'Jewish problem', the Ultra-Orthodox Jews - the charedim (literally, 'God trembling' or 'God fearing') - reject the Zionist's quest for 'normalisation' and maintain that the purpose of the Jews is to be different, as Jews were chosen for a special mission in the world. They also believe that Jews can only return to the Land of Israel in the time of redemption when the Messiah will arrive and the Temple will be re-built in Jerusalem. Religious Zionism integrates the love for the Land of Israel with a love for the Torah. For religious Zionism the creation of the State of Israel, the Six Day War and the gathering of exiles from the Soviet Republic and Ethiopia represent the beginning of Redemption. Within this section extremist groups, such as Gush Emunim, are often described as fundamentalist-type communities (Sprinzak 1993).

As a result of these shifting power relations in the Jewish world, a process of political and ideological polarisation began in Israeli society in the 1970s. Whereas the secular public was largely turning left and adopting liberal, democratic and individualist values, the religious public was generally moving to the right towards nationalistic, collectivistic values and religious conservatism with a focus on the settlement of the Land of Israel (Sabar and Mathias 2003). These global and local influences have impacted on the Jewish community in South Africa and destabilised its traditional notion of identity.

The Jewish community in Johannesburg is frequently described as a cohesive community, with strong Zionist sentiments, and whose religious affiliation is based on the Mitnagdim Orthodox tradition ${ }^{5}$. The Mitnagdim (literally, 'the opponents') were traditional Jews, mostly from Lithuania, who maintained classical Torah learning. The Mitnagdim opposed the Chassidic movement. The latter originated in the eighteenth century in Eastern Europe. It was a social movement that rebelled against the elitist religious establishment and its strict attitude towards the law and Torah studies. It emphasised mystical religious expressions and emotional experiences. 
This article proposes, first, that in order to preserve the content of the Jewish community as Mitnagdim/Orthodox/Zionist/cohesive the boundaries of the community had to be vigilantly controlled and all other voices, past and present, have been silenced. And second, I argue that while South African Jewry in the main is still promoting the traditional content of a Mitnagdim/Orthodox/Zionist/cohesive community, the meanings of these terms have changed over the years and a new identity has been forged: secular Zionism has been shifted towards religious Zionism; moderate orthodoxy has been replaced with Ultra Orthodoxy; and homogeneity has been maintained by advancing exclusion and seclusion. The following sections elaborate on these shifts.

\section{From secular to religious Zionism}

The ethnic cohesiveness of the vast majority of Lithuanian Jews was originally centred on Zionism (Shimoni 1999). This ethnicity was further promoted in South Africa for the following reasons:

First, the structure of the South African society as a whole, with its segmentation into racial and ethnic groups, encouraged Jews to revitalise their own cultural and ethnic identity, including Zionism as a prominent component thereof (Steinberg 1989). Thus while in Western countries, such as the United States and the United Kingdom, Jews avoided joining a Zionist movement for fear of 'dual loyalty' allegations, in South Africa the loyalty to one volk was not only acceptable, but praiseworthy (Campbell 2000).

Second, the foundations of the Zionist movement in South Africa were laid in 1898 before any other ideology could develop. Since it was the first de facto representative institution of the community it concerned itself not only with Zionism but also with local issues, such as helping with the repatriation of Transvaal's Jews after the Anglo-Boer war (Arkin 2002). Consequently it became the most powerful organisation in the Jewish community: 'to be a good Jew in South Africa meant to be a good Zionist' (Shimoni 1980:30). The hegemony of the Zionist movement was such that it even coordinated organisations that in other westernised societies would have functioned as separate bodies, such as the religious Zionist Mizrachi movement.

Third, it is suggested that the later arrival of the Reform movement to South Africa contributed to the dominance of the Zionist discourse because Zionism gave the Jewish community an accepted secular alternative to the Orthodox tradition (Simon 1995). Reform Judaism advocates the modification of the Orthodox tradition in conforming to the exigencies of contemporary life and thought. The movement perceives Judaism as a religion, not a nationality. It therefore advocates the integration of Jews into the states and 
nations where they live. Reform Judaism became popular in the United States and played a central role in the acculturation of Jewish immigrants there but is a minority phenomenon in South Africa.

Fourth, Aschheim (1970) offers an 'insurance policy' theory to explain the Zionist hegemony in South Africa. According to this theory, Zionism is a function of the insecurities of living in a potentially anti-Semitic and explosive multiracial society. Zion therefore became a 'reserve homeland' for the threatened Jews of South Africa.

The Zionism of the South African Jewish community has its own characteristics. Shimoni (1980) maintains that this Zionist identification did not include a strong personal commitment to settle in Israel - referred to as Aliyah (literally, to 'ascend' to the land of Israel) - especially because the Jews in South Africa were confident in the continued viability of their Jewish life-style in South Africa. They therefore identified with the notion of 'returning to Zion' without regarding it as directly applicable to themselves. Aliyah became a significant factor in South African Zionism after the Second World War, but even then it remained modest in scale and mostly corresponded to phases of political turmoil in South Africa ${ }^{6}$. Zionist activities focused mainly on raising funds and supporting the establishment of the Jewish State.

The relationship between the State of Israel and South Africa has vacillated through different phases since 1948, which also impacted on the Zionist inclination of the Jewish community ${ }^{7}$. Afrikaners - in spite of strong anti-Semitic attitudes during the first half of the twentieth century and the presence of pro-Nazi sentiments (Shain 2000) - were sympathetic to Zionism and to the Jewish State, based on their Calvinistic genuflection to the Old Testament. The South African government, under Malan and his successors, allowed the Jewish community to support the State of Israel without the fear of being accused of dual loyalty. In 1961, Jewish community leaders were concerned when Israel sided with African countries in condemning South Africa's racially discriminatory policies. But in the 1970s, Israel and South Africa - both politically isolated - improved their trade and diplomatic relations, including the selling of weapons. This generated new tensions in the Jewish community, which by then mostly identified itself with the progressive movement and with the government's verligte (enlightened) reform policies (Shimoni 1988). In 1987 Israel joined the sanctions imposed by European Common Market countries against South Africa while the Jewish community, like many other white South African communities, supported the lifting of sanctions. The post-apartheid South African government has supported Palestinian national aspirations while retaining reasonable relations with Israel. However, it has not been uncommon for African National Congress (ANC) leaders to express pro-Palestinian and anti-Israeli sentiments (SA Jewish Report, November 17-24, 2000). The ANC 
leaders maintain close ties with the Palestinian Liberation Organisation (PLO) leaders and other Arab countries that were hospitable to them during the apartheid era. It is perceived that the Jewish community is paying the price for the contradictory messages delivered by Israeli diplomacy towards South Africa.

Zionist hegemony began its decline in the 1970s partially as a result of the embarrassment felt by many South African Jews over the diplomatic and trade relations that existed between the State of Israel and apartheid South Africa. This mostly affected the more liberal-minded young Jews who had become disenchanted with Israel's foreign policies and by extension, with Zionism. Subsequently, the Zionist institutional structures were declining. There was an increasing lack of interest in their activities and the South African Jews that left the country seemed to prefer to go to Australia or Canada rather than to Israel. The Zionist institutions became demoralised, realising that they had failed the test of time (Arkin 2002). While in the past the Zionist Federation was home for diverse ideological and political movements, only the Orthodox Mizrachi movement was able to retain viability (Shimoni 2003:209). Subsequently the Zionist movement is currently identified with religious Zionism. This resonates with the expansion of religiosity in the community as the following section clearly illustrates.

\section{From 'non-observant Orthodoxy' to Ultra Orthodoxy}

The religiosity of the vast majority of the community was based on both the Lithuanian Mitnagdim Orthodox tradition (that is, opposition to the Chasidim) already weakened by secularisation in the Old Country and on the lax religious expression of the Anglo Jewry who had arrived in South Africa ahead of the Lithuanians. This resulted in a normative mode of religiosity that has been described by the oxymoron 'non-observant Orthodoxy' (Hellig 1984). Non-observant Orthodox Jews respect the Mitnagdim tradition even though they do not adhere to its prescriptions. Shul (synagogue) attendance and the adherence to specific Jewish rituals provided only a limited measure of religiosity; it was perceived mostly as an occasion for social encounters and for adopting an accepted form of identification. Many Orthodox rabbis came to terms with this phenomenon with the hope that the community would eventually become more observant (Isaacs 1995). South African Orthodoxy was therefore traditionally perceived more as a form of identification than as a matter of religious observance (Aschheim 1970).

Rubenstein (1995) maintains that religious affiliation in South Africa was promoted more by family tradition than by any ideological conviction. He further argues that the elevation of communal unity as the supreme ideological value resulted in much community pressure for accommodation and civility between religious groupings. This in turn inhibited the flourishing of any 
creative Jewish thought. Consequently, the Jews in South Africa are uninformed about modern Jewish movements (Hellig 1984) and have traditionally avoided pursuing serious Jewish studies; hence the paucity of university graduates in Jewish subjects (Harris 1995).

When Orthodoxy became stricter, most South African Jews were willing to accept the changes without opposition because of the respect they had for this tradition, and probably due to their lack of Jewish knowledge to deliberate and question this shift. The community also perceived the traditional rabbinate as the only rightful source of religious authority. Consequently, the Orthodox rabbinate, in particular the Orthodox Chief Rabbi and the Beit Din (the Jewish court), continued to exercise power over a wide range of issues, such as conversion, kashrut (Jewish dietary laws) and synagogue standards.

The Ultra Orthodox and the Reform movements made relatively little headway in the early days of the community.

The Ultra Orthodox was confined to a small splinter group of German immigrants that in the 1930s had established a congregation known as Adat Yeshuron, in the Johannesburg suburb of Yeoville. In 1969 a Kollel was formed to provide married men with intensive Torah studies.

The Reform movement (later known as the Progressive movement) was introduced to South Africa in 1933. From its inception it encountered strong resistance from the Orthodox rabbinate based on Orthodoxy's conviction that the Hallacha (Jewish laws) cannot be bent (Hellig 1984). The only concession ever given to the Reform movement was to allow a Reform Rabbi to sit on the stage alongside other officials at the annual memorial for Holocaust victims, as well as at other non-religious public gatherings (Shimoni 2003; Saks 1999). According to a survey in 1974, 77.1 per cent of South African Jewry supported Orthodox synagogues while 16.6 per cent supported Reform temples (Hellig 1984). Hellig maintains that the Reform movement never developed further in South Africa since the Orthodox establishment allowed for the participation of non-observant Jews who traditionally would have been excluded from such synagogues. She further suggests that the broader religious context in South Africa - especially the 'state' Reform Church ethic that was puritan and extremely traditional - did not provide a favourable place for the growth of Reform Judaism. Moreover, the rise of Reform Judaism is usually associated with a high level of intermarriage and South Africa's low intermarriage rate negates this necessity.

South African Reform Judaism is a unique phenomenon especially as it was never anti-Zionist and as it adhered to many of the religious rituals even though Reform Judaism practises the rites of passage differently from the Orthodox. From the late 1950s, after the charismatic Reform leader Rabbi 
Weiler emigrated to Israel, the movement began to decline. It again suffered a series of blows to its morale and membership in the 1980s and 1990s, mostly related to personality issues. Thus by 1998, there were only ten official Reform congregations in South Africa, three of which were in Johannesburg. It is currently observed that the Reform movement is an aging community that has failed to attract younger members. According to a 1998 national survey, eight per cent of Jews in the Johannesburg area still belong to the Reform movement, which seems to have more burial than marriage ceremonies (Saks 1999).

The relationship between the Reform and the Orthodox communities has remained tense. Disputes have flared up from time to time but have seemingly diminished over the past few years 'with the Orthodox feeling less threatened and the Reform being less militant' (Saks 1999:72). Recent events, however, point to underlying tensions. In Cape Town, religious leaders avoided attending the 2000 Holocaust Day memorial ceremony as a Reform Rabbi was to be the guest speaker (SA Jewish Report, June 8, 2000). During that same year, the SA Jewish Report, under pressure from the Chief Rabbi, stopped running a weekly column by a journalist who was a member of the Reform movement because of his harsh criticism of mainstream Orthodoxy and its leaders ${ }^{8}$. The SA Jewish Report's board of directors made it clear that one could only debate Judaism within the discourse of Orthodoxy; and that for the preservation of the unity of the community, different views should not be voiced:

Allowing for difference of opinion is one thing, but it was never the intention of those who founded the newspaper to provide a platform for regularly attacking Orthodox Jews and Orthodox Judaism. Such a paper, apart from becoming a divisive element, rather than the unifying force it was intended to be, would inevitably be rejected by the mainstream community. (SA Jewish Report, October 6-13, 2000)

In the 1960s and 1970s - as the more enlightened outward-looking rabbis left South Africa owing to their conviction that to continue living in apartheid South Africa was against their conscience (Shimoni 2003), and with the resurgence of Ba'alei Teshuva (literally, 'those who return') movements in the Jewish world - a large number of strictly Orthodox, yeshiva-trained rabbis from overseas arrived in South Africa. It was perceived that most of these rabbis, based on their Ultra Orthodox and non-secular education, tended to be inward-looking and insular. They tended to be concerned only with increased Jewish observance and were detached from any sense of responsibility to the community or wider society. The new rabbis slowly transformed a significant minority of the community through their educational systems, their charisma and their dedication to religious transformation. Some of these rabbis filled positions at a number of mainstream (Mitnagdim) synagogues. In spite of their relatively small numbers, the Ultra Orthodox voice is vociferous, and their worldview began 
slowly to occupy the common sense of many community members. The latter had very little Jewish knowledge to debate the issues brought up by the Ultra Orthodox adherents (whose Jewish knowledge is also debatable), were just indifferent to the religious authority, or had no other ideology to follow.

The first to arrive were the Chassidic Jews. The Lubavitch foundation movement was established in South Africa in 1972 under the control of Rebbe Menachem Mendel Schneerson, from his stronghold in Crown Heights, Brooklyn, New York ${ }^{9}$. The view of the Lubavitchers is that Judaism involves the totality of the individual. They implemented an effective outreach programme, which attempted to spread the message of ahavat Israel - the love of all Jews. Hellig (1984) observes that one of the successes of the Lubavitch movement is its mastery of public relations and the media, a strategy used by many fundamentalist-type groups. They use colourful pamphlets to encourage the performance of mitzvot (commandments) and they work tirelessly to reach out to all Jews in the community.

In 1986, the Ultra Orthodox (Mitnagdim) Ba'alei Teshuva movement Ohr Sameach - established branches in Johannesburg predominantly in the suburb of Glenhazel. Ohr Sameach initially catered to young adults by creating a learning centre that encouraged meetings three times a week, held at first in the home of one of the rabbis. The group quickly outgrew the space, its popularity stemming from its ability to establish a trend by which it became not only acceptable but socially advantageous to attend shiurim (literally, 'lessons') (Kaplan 1998b). These lectures were delivered by guest speakers from abroad and usually focused on the immediate emotional concerns of the audience, in particular, on psychological issues such as interpersonal skills, relationships, and how to deal with the stresses of modern life.

Ohr Sameach tried to avoid conflicts with various subgroups within the Orthodox community. Yet at the same time it attempted to appeal to as broad a spectrum of Orthodox people as possible. In the 1990s, the organisation established more branches in different suburbs, creating tight religious communities that have become highly influential elements in Johannesburg Jewish life. Furthermore, in 1996 Aish Hatorah opened its own branch in Johannesburg, providing more outreach programmes to the community. The development of the Ba'alei Teshuva movement in Johannesburg is connected to a related phenomenon: the growth of the shtibl - the small, intimate, traditional house of prayer associated with the Eastern European Jews - as an alternative to the large, formal synagogues, which were typical of the British Commonwealth style. Consequently, the big synagogues and the Anglo-Lithuanian tradition were challenged by the proliferations of these small shtibl-type congregations. While, in the main, the Orthodox establishment welcomed the turn towards religiosity, it objected to the balkanisation of the community, the loss of central control, and the tendency 
for these shtibls to become independent, separatist institutions (Harris 1999). There was also the possibility of a lack of standards and the danger that they would provide an opportunity for a breakaway from the religious establishment for those members who were contemptuous of it and felt no responsibility towards the larger Jewish community (Bernhard 1995).

In 1995, Rabbi Bernhard declared that 'virtually every family has been touched by the resurgence of Yidishkayt [the culture that goes with the Yiddish] in South Africa. Everyone knows somebody who is frum [religious]' (Bernhard 1995:77). Shimoni (2003) maintains that this move towards greater religiosity should not be exaggerated and that most South African Jews may still be characterised as 'non-observant Orthodox'. However, the lack of clear consensus and standards by which to measure religiosity means that both arguments are located in the realm of perception.

The success of the Ba'alei Teshuva movement in South Africa is attributed to four main factors:

First is the affinity that the community has to Orthodoxy. Most South African-born Jews have been raised in homes in which there was more sympathy for Orthodoxy than knowledge of it. Thus they were natural candidates for a more intense version of Orthodox Jewish belief and practice. Moreover, the Zionist ideology is based on the Jewish tradition; Zionism therefore never rejected Judaism. By and large even non-observant Jews began to conform to the stricter orthodox standards, especially those concerned with various rites of passage and kashrut. Shimoni (2003) maintains that this did not take the appearance of a religious 'cult' but rather became the norm for the community as a whole. It is perceived that South African parents - even those who practise virtually no Jewish law - accept their children's greater involvement in and allegiance to Orthodoxy (Kaplan 1998b, Roer-Strier and Sands 2001).

Second, it is hypothesised that the rapid transformation and the insecurities created by social changes in South Africa after 1994, as well as the increased level of crime, pushed more Jews to escape into the warmth of communal seclusion provided by the religious institutions. They seem to seek the 'spiritual solace and orderly life that comes with submission to the authority of rabbinical mentors and immersion in the all encompassing orthodox code of living' (Shimoni 2003:234).

Third, the increase in the level of religious observance in the community went hand in hand with the decrease of the Zionist hegemony, a process discussed earlier in this article. It is argued that the disillusion with the Zionist ideology created an ideological void that was filled by religiosity (Shimoni 2003). 
Fourth, while the Ultra Orthodox educational programmes became trendy and popular, alternative scholarly programmes stressing liberal values drew an extremely limited audience. Some researchers tried to explain this phenomenon by looking at the historical and cultural background of the Jewish community. It is widely accepted that Jewish identity in South Africa is based 'on spontaneous sentiment rather than a deep involvement in religious practice or culture and learning' (Steinberg 1989:363). Consequently, it is viewed that the charisma of the speakers, rather than intellectual argumentation, could have had an impact on the community (Kaplan 1998a). Furthermore, it is perceived that living and being educated under the apartheid regime has trained South African society not to engage in critical thinking processes and to avoid asking too many questions (1998a). Kaplan observes that the creation of an open, democratic order has not changed this mentality but rather initiated a trend among many Jews (and other white groups) to withdraw from general society and to form tighter close-knit subunits. This trend has manifested in the increasing social ghettoisation around shtibls.

Fifth, modern religious fundamentalism often cloaks itself in the language and authority of traditional faith. The appeal of the Ultra Orthodox movement in South Africa, especially Ohr Sameach, is that they give the impression that they are the only authentic Jews who keep the narrative of the 'imagined' community; that is, the Mitnagdim/Zionist/Orthodox/homogeneous community. While the Mitnagdim element is self-evident, it is not an Orthodox but rather an Ultra-Orthodox movement. The Zionist element is even more suspect. The Ultra Orthodox movement has a strong emphasis on Torah learning, uncompromising adherence to the hallacha and opposition to Zionism as a political ideology. Yet, they have many learning centres in Israel, to which they send a number of followers, some of whom choose to stay in Israel in closed communities. They may therefore give the perception of being Zionists, but this is neither secular Zionism, nor religious Zionism. Their attachment is to the Land of Israel rather than to the State of Israel.

It appears therefore that by the end of the twentieth century - due to both global and local processes - the identity of the Jewish community in Johannesburg shifted from an identity based on ethnicity to that based on religion with a fundamentalist undertone. The official researcher at the South African Jewish Board of Deputies, an Ultra Orthodox Jew, therefore enthusiastically maintains that:

Despite ongoing attrition through emigration, which has led to the common perception overseas that the community is one in apparently terminal crisis, in many ways South African Jewry is experiencing $a$ golden age in terms of Jewish commitment and involvement. These have been raised to levels seldom equalled and certainly not surpassed by any other Diaspora community. (Saks 2003:10, my emphasis) 
For liberal thinkers such as Dennis Davis ${ }^{10}$, however, this 'golden age' means:

...the closure of the Jewish mind, the creation of 'other' within Jewish ranks, a hatred of difference and a consequent rejection of any possible reconciliation between Muslim and Jew, Palestinian and Israeli. Of equal importance, this form of Judaism promotes the group at all costs. The individual is then subsumed under the weight of obligations to the group, Judaism then becomes a custom-made product, and the possibility of individual development implodes. (Davis 2000:209, my emphasis)

It is evident that while the secular Zionist hegemony was a relatively unifying factor, the perceived unity of the community began to disperse with the decline of Zionist ideals and organisations and the proliferation of religious activity, coupled with the underlying rivalry between the various splinter groups (Hellig 1984). Already in the late 1980s there was a struggle for control of the community between those who favoured the continuation of appointing the Chief Rabbi from the Mitnagdim tradition and those who wanted a Rebbe who practiced Chassidism (Kaplan 1991). Consequently, Kaplan believes that 'the appointment of Chief Rabbi Harris [was] an overwhelming victory for the determination of the majority of the Johannesburg Jewry to maintain the tradition observed from its earlier years' (1991:252). The argument became even more intense with the retirement of Chief Rabbi Harris and the search for a new chief rabbi in 2004. While there was no transparency with regard to the selection processes it was clearly a tight competition between a mature and experienced Lubavitch rabbi and a young and inexperienced rabbi affiliated to Ohr Sameach (SA Jewish Report, June 16-23, 2005). In this battle for the leadership the narrative of the community still proved dominant as the religious leaders preferred to appoint an Ohr Sameach affiliated rabbi - in the Mitnagdim tradition - than a Chassidic rabbi ${ }^{11}$.

The new Chief Rabbi, Dr Warren Goldstein (2005- ), seems to encourage the institutionalisation of certain Ultra Orthodox customs in the community, by making himself absent from public gatherings where women are allowed to sing or Reform rabbis to speak (SA Jewish Report, June 3-10 and November 18-25, 2005). It is possible that through his obvious actions, Ultra Orthodox practices might increasingly form the content of the community at the same time as they could set the boundaries that would broaden the gap between secular and religious Jews in South Africa.

The shift toward greater religiosity was also evident in the recent restructuring (2001-2003) of Jewish community schools in Johannesburg (Herman 2006). While the schools had reflected the moderate orthodoxy that was hegemonic in the community, the restructuring was a clear attempt to establish 'born again' Jewish community schools based on religious extremism. The religious control over the schools means dominating the 
common sense and providing the content of the Jewish community, thus shaping the identity of the next generation.

\section{Homogeneous community}

The third factor that has shaped the character of the Jewish community in South Africa has been its profound pressure to conform (Aschheim 1970), its inclination to avoid controversy in the interest of maintaining Jewish unity, and the avoidance of any debate on issues that might come to give Jews a bad name in the eyes of the gentile majority. The pressure for conformity has been reflected in the official Jewish attitudes towards the National Party and towards those individuals who resisted the apartheid regime.

Most South African Jews came from an environment of oppression in Lithuania and stepped into a society in which their 'white' skin colour instantly and automatically made them part of the white minority that ruled over the black majority. Jews accepted these privileges with 'both hands' and established themselves in industry, commerce, mining and the professions, fitting well into a comfortable middle-class position. The victory of the Afrikaner Nationalists in the 1948 elections was first seen as a threat to the community, based on the Nationalists' inclusion of some Nazi supporters in their ranks, and their record of anti-Semitism, which restricted Jewish immigration in the 1930s and barred Jews from membership in the party's leading Transvaal province (Shain 2000, Shimoni 2003). As it turned out the National Party did not adopt an anti-Semitic policy, instead forging a relatively cordial relationship with the Jewish community albeit with isolated, threatening warnings from government leaders, either out of anger at the anti-apartheid actions of individual Jews, or because of the Israeli vote against South Africa in the United Nations in $1961^{12}$.

The Jewish community found itself in a dilemma of conscience: should it be loyal to the country that gave them safe haven and prosperity; or should it oppose a system of government that oppressed other people, especially in view of the Jewish history of persecution? The compromise reached by the South African Jewish Board of Deputies - the official body representing the Jewish community - was that Jews as citizens could behave according to their conscience, but that the Board itself would not become involved in the politics of the country (Goldberg 2002). Shimoni (2003) maintains that deep-seated fears underlay this compromise and that the Jews as a community felt themselves to be hostage to Afrikaner nationalist goodwill. He argues that in this sense the Board of Deputies acted for the benefit of the community whose welfare depended on conformity with the white consensus, and that its actions were "characteristic of minority group behaviour - a phenomenon of self-preservation, performed at the cost of moral righteousness' (Shimoni 2003:276). Others argue that Jewish leadership ran 
scared and that their fears were exaggerated ${ }^{13}$.

The point that I would like to make here, however, is concerned with the attitude of the Jewish leadership towards those Jews who stood by their moral conscience and struggled against the apartheid regime. While the vast majority of Jews complied with apartheid (like the rest of the white population) and benefited from it, many white radicals and liberals were Jews. The message of the community leaders to those individuals was that they were endangering the community by their anti-government acts. The Board of Deputies and the majority of the community consequently disassociated themselves from these activists, ignored and ostracised them. Inevitably, these activists did not fit into the dominant narrative. They were mostly secular Jews or atheists, socialist, anti-capitalist or anti-Zionist. Subsequently, they were often considered as 'non-Jewish Jews' who cared for the blacks but not for their own community (Suttner 1997). It is evident that the establishment did not support liberal thinkers who would not 'toe the line' and did not conform to the majority.

The case of Claudia Braude demonstrates that the silencing of nonconformists in the community is continuing even after the South African transformation. In 1997 Braude wrote an article criticising the behaviour of Jewish leaders under apartheid. She mentioned in particular Dr Percy Yutar, who was the prosecutor at the trial in which Nelson Mandela was sentenced to life imprisonment, while at the same time being elected head of the United Hebrew Congregation, Johannesburg's group of Orthodox synagogues. The article was not allowed to be published in Jewish Affairs, even though Braude herself was on the editorial board of the magazine. She resigned as a result and proceeded to publish her views in the general press, an action that was highly criticised. For Campbell (2000) this is another example of the Board of Deputies' refusal to allow confrontation and open debate even in post-apartheid times. Shimoni, on the other hand, ends the discussion on Braude with a patronising statement reflecting the view of those members of the community he claims to have observed at a public meeting:

In the eyes of the other Jews who were not inclined to be so judgemental, Braude's views, however well intentioned, appeared to be no more than the self righteous harangue of a post apartheid youngster insufficiently mature to appreciate the universal phenomenon of minority group behaviour. (Shimoni 2003:268)

The case of Braude demonstrates that debate could only take place within the defined boundaries of the mainstream community. Braude's case became known simply because she defied the establishment and did not agree to be silenced. For this she was harshly condemned.

It is evident that the Jewish community's highest value has been its unity and conformity, which resulted in intolerant behaviour towards those with 
different or liberal ideas. This was not confined only to the political arena, in which such behaviour may be excused based on never-ending fears of anti-Semitism. As already illustrated in the tension between Reform and Orthodox, the same approach has been used to censor any divergent views within Judaism. Open debate or criticism of the establishment has been curtailed in order not to 'divide the community'. By silencing dissenting voices the 'imagined' cohesiveness of the community has been preserved and its boundaries have been maintained.

The belief that debate should be avoided in order not to destabilise the community has facilitated in some instances the institution of undemocratic decision making processes, whereby selected factions within the community can enforce their agenda on the larger community. This was clearly the case in the restructuring of the community schools as this pretence of 'homogeneous community' was used by what has been described as the 'rightist alliance', namely the Orthodox, the Ultra Orthodox and the community financial elite, to ignore the majority parents and pupils constituency. In that scenario the narrative of the 'homogeneous community' had contributed to silencing the opposition to the restructuring process and had facilitated a further shift of the community schools to the 'right' (Herman 2006).

While debate is not encouraged, the Ultra Orthodox/Orthodox movements send messages of great consensus and unity, thus sustaining the narrative of homogeneous community. In this 'imagined' community, parents are 'happy' that their children are becoming more 'right-wing' ${ }^{14}$ and the various religious movements live in harmony:

I think that we have a very unique form of Judaism, which Jewish communities around the world can learn a lot from. What we have here is a unity, an inclusivity and tolerance, in which, for example, Jews who are not fully observant can feel comfortable in fully Orthodox shuls and in which the various movements, whether Mizrachi, Lubavich, Ohr sameach or Aish Hatorah, can work together on many projects. (Goldstein 2004:30-32)

In this study I have suggested that not everyone is happy with the turn to the 'right', and that there are no idyllic relationships even within the 'rightist alliance' wherein some modern Orthodox parents object to their children's turn towards extremism, and Ohr Sameach is 'just waiting to go in and take as many people ... out of Mizrachi, as they possibly can, and out of the general system' (2006:298). While the rhetoric of the 'homogeneous community' does not seem to apply even within the 'rightist alliance', it definitely fails to include the 'others', such as the non-observant Orthodox Jews, the secular Jews and the Reform Jews, who feels marginalised and Disempowered $^{16}$, even though it is perceived that the majority of the community is 'still by far ... the middle of the road, traditional but generally not fully observant shul-going' Jews ${ }^{17}$. The recurring message is that Jews 
in South Africa either join one of the religious communities or they may lose their Jewish identity:

We cannot sustain a middle road anymore. We must move to a more observant path or we will lose our Jewish identity. There were two directions the youth are taking simultaneously. On the one hand, there was a revolution with many youth coming back to religion, but at the same time there was a crisis because the youth were moving away, being assimilated and intermarrying ${ }^{18}$.

\section{The Jewish community is the post apartheid era - forging new Identity}

The transition in South Africa has set forces in motion that have progressively eroded the unique social structure that $h$ ad been so successful in maintaining the content and the boundaries of the Jewish community until the 1990s. At the same time, the political and ideological struggles in Israel, which have polarised the Jewish world, have further destabilised the Jewish identity of many South African Jews. The dominant discourse of an Orthodox/Mitnagdim/ Zionist/cohesive community has become infused with different meanings. I doubt whether the Mitnagdim/Lithuanian concept is even familiar to many third generation South African born Jews, yet this narrative is still having an impact on the community leadership and the choices that it makes. Expressions of Zionism have become mostly religious rather than secular, and the resurgence of religion has balkanised the community into shtibls. Ultra Orthodox practices and thoughts have permeated the traditional modern Orthodox synagogues without the community at large having enough Jewish knowledge to be aware of the differences. Moreover, the boundaries of the 'imagined community' have been maintained mostly by ignoring or silencing different voices - either political or ideological. Consequently, the community has not been exposed to debate and different worldviews, and hence to learning and intellectual stimulation. The emigration of many intellectual and liberal thinkers as a response to the apartheid policies further aggravated this situation. South Africa's transformation to democracy has not seemed to open up the community to new possibilities, but has instead made it more inward-looking and insular. Global anti Semitism, as well as the South African government's close ties with the Arab world have reinforced a feeling of isolation and fear, and have pushed many Jews in South Africa into the seclusion of a close tight society.

Sarason rightly maintains that "we do not become aware of the social change until it hits us in the face, long after the seeds of change have sprouted' (1998:29). From time to time, certain events alert the community to the ideological and political changes, such as the ideological restructuring of the community schools mentioned earlier. In February 2005, a gay Orthodox Rabbi was banned from speaking at several venues along with the screening of a controversial documentary that looks at the struggle of gay 
Jews to find a place in Orthodox Judaism. The leadership refused even to debate this topic ${ }^{19}$. Later on in November 2005, Chief Rabbi Goldstein enraged many community members when he refused to attend the memorial of Yitzchak Rabin as he was meant to share a speaking platform with a Reform rabbi $^{20}$.

Apple (2001), who examines the working of the 'rightist alliance' that has increasingly turned western societies towards the 'right', maintains that the success of the 'right' is never guaranteed, as there are counter-hegemonic movements and people who have not been integrated under the hegemonic umbrella. He therefore tends to adopt a position which he calls 'optimism, but without illusions' (2001:62) - that there is a hope for a better society, where people would realise that the shift to the 'right' may actually be 'wrong' since it 'stifle[s] or trivialise[s] a vision of democracy that is based on the common good' (2001:230).

And indeed some counterforce to the Ultra Orthodox/Orthodox hegemony has been created in the Jewish community, mostly emanating from among liberal-minded academic, secular and Reform Jews ${ }^{23}$, but also from the mainstream Orthodoxy ${ }^{24}$. In the public sphere, this has taken the form of articles, letters or petitions in the local newspaper. Occasionally, there are public debates on certain issues where speakers from different perspectives are invited to air their views. These attempts to challenge the new content and boundaries of the community, however, are small and dispersed and might not be sustainable without a political force behind them. The success of the counterforce is dependent on the community's willingness to face and debate its shifting identity, to broaden its boundaries and to create a new content that celebrates diversity, inclusivity, tolerance and openness to others. It is the challenge that the Jewish community in South Africa needs to face in order to maintain its viability and creativity.

\section{Notes}

1. Lithuania was a province of Czarist Russia. It was an independent nation from 1918 to 1940 until it became reincorporated into the Russian empire in the form of the Soviet Union.

2. The Quota Bill of 1930 and the Alien Act of 1937 restricted Jewish immigration from Eastern Europe and later on from Germany (Shain 2000).

3. JPR Report (September 1999). Jews of the New South Africa: Highlights of the 1998 national survey of South African Jews. Institute for Jewish Policy Research in association with the Kaplan Centre, Report No.3.

4. Below ten per cent in 1998 survey, see Note 3 above. 
5. See for example: 'Unity in South Africa saving grace - Rabbi Wein'. SA Jewish Report, September 30 - October 7, 2005.

6. Larger numbers of immigrants to Israel were registered after the Sharpeville (1960) and Soweto (1976) riots, indicating that South African Jews tend to go to Israel when they feel under threat. Source: Align Statistics http://www.jewish.org.za/php/3/community.php3?action=present.

7. For a detailed account on the rel ationship between Israel and South Africa and its impact on the Jewish community, see Shimoni 2003 and Goldberg 2002.

8. 'Steven Friedman is arrogant and ill-informed', SA Jewish Report, September 18, 2000. See also Letters to the Editors, SA Jewish Report, October 6-13, 2000.

9. The Rebbe was laid to rest in June 1994 and is expected to return soon to complete the redemption in his capacity as the messiah (Berger 2001).

10. A Professor of Law and a Judge of the High Court in Cape Town.

11. Personal communication with the late Chief Rabbi Harris (February 2003).

12. Benjamin Pogrund, 'A deafening silence, unconscionable or excusable? A look at the actions of the Jewish community in South Africa through the darkest period of apartheid rule', Ha' aretz [online] December 26, 2003.

13. Mervyn Smith's presentation at the conference of the Jewish Board of Deputies, Johannesburg, September 7, 2003.

14. Task Force Report, 'The South African Jewish Day School System', Comments by Chief Rabbi Harris. Office of the Chief Rabbi, Johannesburg, October 21, 2002.

15. 'A community in perpetual crisis', The Sunday Independent, September 19, 2004.

16. 'Judaism in Johannesburg: strength in diversity', SA Jewish Report, February 21-28, 2003.

17. 'Youth carrying the Jewish vision', SA Jewish Report, October 25 - November $1,2002$.

18. Jews outraged at ban on gay rabbi's talks. Sunday Times, February 27, 2005.

19. Statement from the office of the Chief Rabbi. SA Jewish Report, November 18$25,2005$. 
20. 'Promoting Jewish pluralism', SA Jewish Report, November 25 - December 2, 2005. Paid-for notice by the South African Union for Progressive Judaism. SA Jewish Report, November 25 - Decembr 2, 2005.

21. 'When conservatism is clothed as Orthodoxy', SA Jewish Report, 12-19 August 2005. 'Clinging to outdated customs', SA Jewish Report, November 25 -

December 2, 2005. 'Johannesburg Jewry 2005 - unity or fragmentation?', SA Jewish Report, December 2-9, 2005.

\section{References}

Apple, MW (2001) Educating the 'Right' Way: markets, standards, God and inequality. London: Routledge and Falmer.

Arkin, M (2002) 'The Zionist Federation umbrella', Jewish Affairs, Spring 32(24).

Aschheim, SB (1970) 'The communal organisation of South African Jewry', Jewish Journal of Sociology 12(2).

Bernhard, NM (1995) 'The shtibilisation of the community, good or bad?', Jewish Affairs, Autumn.

Campbell, JT (2000) 'Beyond the pale: Jewish immigration and the South African left', in M Shain and R Mendelsohn (eds).

Cohen, EH (1995) 'Components and symbols of ethnic identity: a case study in informal education and identity formation in Diaspora', Applied Psychology: an international review 53(1).

Davis, D (2000) 'Jews and the open society', in M Shain and R Mendelsohn (eds).

Gitelman, Z (1998) 'The decline of the Diaspora Jewish nation: boundaries, content and Jewish identity', Jewish Social Studies 4(1).

Goldberg, A (2002) Profile of a Country: South African Jewry. Johannesburg: Rabbi Alloy Foundation Trust.

Goldstein, W (2004) 'Interview', Jewish Affairs, Pesach 59(1):30-32.

Harris, CK (1995) 'The elusive balance: The Jewish day school predicament', Jewish Affairs, Spring. (1999) 'The Ba'alei Teshuva phenomenon and South African Jewry', Jewish Affairs, Autumn.

Hellig, J (1984) 'Religious expression', in M Arkin (ed) South African Jewry: a 
contemporary survey. Cape Town: Oxford University Press.

Herman, C (2006) Prophets and Profits: managerialism and the restructuring of Jewish schools in South Africa. Cape Town: HSRC.

Kaplan, ED (1998a) 'Jewish educational trends in South Africa today', Journal of Jewish Education 64(3).

(1998b) 'Practice of Judaism in South Africa', http://www.danakaplan. com/Articles/SA/SouthAfricaencyclopediaofJudaism-pp1347-1357.pdf

Kaplan, M (1991) 'Envoy', in M Kaplan and M Robertson (eds) Founders and Followers: Johannesburg Jewry 1887-1915. Cape Town: Vlaeberg.

Kopolowitz, S (1997/8) 'Issues facing the South African Jewish community: the challenge to Jewish professionals', Journal of Jewish Communal Services, Winter/Spring.

Roer-Strier, D and R G Sands (2001) 'The impact of religious intensification on family relations: a South African example', Journal of Marriage and Family 63.

Rubenstein, I (1995) 'Jewish education in a changing South Africa', Jewish Affairs, Spring.

Sabar, N and Y Mathias (2003) 'Curriculum planning at the threshold of the third millennium: the Israeli case', in WF Pinar (ed) International Handbook of Curriculum Research. New Jersey: Erlbaum.

Saks, D (1999) “'Jewish pluralism”: a South African perspective', Jewish Affairs, autumn.

(2003) South African Jewry: a contemporary portrait. Jerusalem: The institute of the World Jewish Congress.

Sarason, SB (1998) 'World War 2 and schools', in A Hargreaves, A Lieberman, M Fullan and D Hopkins (eds) International Handbook of Educational Change. Dordrecht: Kluwer Academic.

Shain, M (2000) "'If it was so good, why was it so bad?" The memories and realities of anti-Semitism in South Africa, past and present', in M Shain and R Mendelsohn (eds).

Shain, M and R Mendelsohn (eds) (2000) Memories, Realities and Dreams: aspects of the South African Jewish experience. Johannesburg and Cape Town: Jonathan Ball. 
Sheffer, G (2002) 'A nation and its Diaspora: a re-examination of Israeli-Jewish Diaspora relations', Diaspora 11(3).

Shimoni, G (1980) Jews and Zionism: the South African experience 1910-1967. Cape Town: Oxford University Press.

(1988) 'South African Jews and the apartheid crisis', in D Singer D and R Seldin (eds) American Jewish Year Book 1988. New York: The American Jewish Committee and the Jewish Publication Society.

- (1999) 'From one frontier to another: Jewish identity and political orientation in Lithuania and South Africa', in SL Gilman and M Shain (eds) Jewries at the Frontier: accommodation identify conflict. Urbana and Chicago: University of Illinois Press.

- (2003) Community and Conscience: the Jews in apartheid South Africa, Cape Town: David Philip.

Simon, J (1995) 'Shaping the patterns of South African Jewish observance', Jewish Affairs, Autumn.

Sprinzak, E (1993) 'The politics, institutions and culture of Gush Emunim', in LJ Silberstein (ed) Jewish Fundamentalism in Comparative Perspective: religion, ideology, and the crisis of modernity. New York University Press.

Steinberg, B (1989) 'South Africa: Jewish education in a divided society', in HS Himmelfarb and D DellaPergola (eds) Jewish Education Worldwide: cross cultural perspectives. Lanham, Maryland: University Press of America.

Suttner, I (ed) (1997) Cutting Through the Mountain. London: Viking. Transformation 63 (2007) ISSN 0258-7696 45 